\title{
Trabakul Sveti Ivan - jedan od najstarijih drvenih plovećih brodova na Jadranskom moru
}

\section{Trabaccolo St John - One of the Oldest Wooden Ships in the Adriatic}

\author{
Margarita Bego \\ Sveučilište u Dubrovniku \\ Odjel za umjetnost i restauraciju \\ e-mail: margarita.bego@unidu.hr
}

\section{Sažetak}

Korištenje drvom za gradnju brodova potječe još iz pretpovijesti. Povijesni izvori ukazuju da su u dalekoj prošlosti Dalmacija i dalmatinski otoci bili vrlo šumoviti, što potvrđuju razni pisani dokumenti. Iz zapisa vidljivo je da su počeci drvno-prerađivačke djelatnosti na području Republike Hrvatske bili najprije na obalama Jadranskog mora, gdje se posebno prerađivalo i pripremalo brodograđevno drvo. Stoga će rad predočiti važnost drva u izradi i održavanju drvenih brodova, a kao primjer prikazat će se jedan od najstarijih, ako ne i najstariji trabakul, koji još uvijek plovi Jadranskim morem. To je trabakul Sveti Ivan izgrađen, 1878. u Ladjedjelnici Piran obitelji Apollonio. Trabakul je izgrađen od više vrsta drva: hrasta, ariša, bora i duda. Konstruktivni dijelovi donjeg dijela broda izrađeni su od piljenih i tesanih dasaka. Površinski je obrađen "dihtovanjem", klasičnim kalafatavanjem te je zbog toga vodonepropusan i zaštićen starim tradicionalnim metodama nanošenjem paklinom.

\section{Summary}

The use of wood in shipbuilding industry dates back to prehistoric times. Historical sources prove that in the distant past Dalmatia and the Dalmatian islands were densely forested, which is confirmed by various written documents. The records show that the beginnings of woodworking in the territory of the Republic of Croatia first occurred on the Adriatic coast where wood used in shipbuilding was processed and prepared with particular regard. The paper points out the importance of wood in the construction and maintenance of wooden ships on the example of one of the oldest, if not the oldest trabaccolo still sailing on the Adriatic Sea. It is trabaccolo St John built in 1878 in the Piran shipyard of the Apollonio family. The trabaccolo is made of several types of wood: oak, larch, pine and mulberry. The structural members of the lower part of the ship are made of sawn and carved boards. The traditional caulking method was used to seal off its surfaces and thus make them watertight and protected by the old method of applying pitch.
DOI 10.17818/NM/2020/3.8

UDK 629.51/.53

Pregledni rad / Review

Rukopis primljen / Paper accepted: 12. 5. 2020

\section{KLJUČNE RIJECI}

drvo

trabakul

dijelovi trupa

savijanje drva

kalafatavanje

\section{UVOD / Introduction}

O povijesti drvenih brodova napisano je bezbroj knjiga i članaka pa je teško odrediti što bi još bilo zanimljivo objaviti ljubiteljima i znalcima drvenih brodova. Hrvatska tradicijska brodogradnja, zahvaljujući dugovječnosti i značenju s kulturno-povijesnog, umjetničkog, ambijentalnog, etnološkog i znanstvenoga stajališta, važan je dio hrvatske kulturne baštine te nacionalne materijalne i duhovne kulture pa se u posljednje vrijeme sve više pozornosti posvećuje njezinu očuvanju i popularizaciji (Markovina, 2017.).

Zakonom o zaštiti i očuvanju kulturnih dobara 1999. uveden je termin kulturno dobro, umjesto spomenik kulture (URL 1). Među pokretna kulturna dobra uvrštena su prometna i prijevozna sredstva i uređaji, među koje spada i brod (Kisić, 2004.). Kategoriji zaštite nematerijalnih kulturnih dobara raznih oblika i pojave duhovnog stvaralaštva što se prenose predajom ili na drugi način pripadaju i tradicijska umijeća i obrti. Time je u zaštitu uključeno sve što interdisciplinarno spada u istraživanje tradicionalne gradnje drvenih brodova (usmena predaja, stari nazivi i sl.) (Kisić, 2004.).
U Hrvatskoj je desetljećima bilo prilično zapostavljeno shvaćanje vrijednosti pomorske baštine, koja je dio mediteranskoga pomorskog naslijeđa. Potrebno je još vremena da šire društvo i mlađi naraštaj valoriziraju njezinu izuzetnu vrijednost za Hrvatsku. "Metodologija i kriteriji za procjenu autentičnosti tradicijskog broda" autora Velimira Salamona i Nenada Bobanca u izdanju HAZU temelj je za popis svih brodova na Jadranu i procjenu njihove autentičnosti te kulturno-povijesne vrijednosti (Salamon i Bobanac, 2005). Drveni je brod nacionalno kulturno dobro, spomenik kulture svake pomorske zemlje, koji valja staviti pod režim zaštite, kao i svako drugo kulturno dobro (URL 2).To su prepoznale mnoge europske zemlje i sustavno krenule u spašavanje, održavanje, ali istovremeno i promociju svoje pomorske kulture.

Od strane Europske komisije, a pod pokroviteljstvom UNESCO-a, osnovano je 2005. udruženje European Maritime Heritage - EMH za zaštitu pomorske povijesti i tradicionalnih brodova. Zemlje članice EMH-a jesu: Danska, Finska, Francuska, 
Njemačka, Nizozemska, Norveška, Švedska i Velika Britanija. Udruženju su još pridruženi razni muzeji i udruženja iz Belgije, Danske, Španjolske, Finske, Francuske, Njemačke, Nizozemske, Norveške, Portugala, Švedske, Velike Britanije, Estonije i Poljske. EMH je nevladina organizacija za privatne vlasnike tradicionalnih brodova, kao i za pomorske muzeje i druga zainteresirana tijela (llijanić, 2010.).

Brodovlje Dubrovačke Republike, koja je bila cvijet hrvatske kulture, znanosti i filozofije, simbol je našeg pomorstva. Brodogradnja i brodarstvo općeg naziva slobodarstvo (Libertas) bili su pojam diplomacije i aktivna suživota različitih kultura (Stulli,1984). Vrlo važni u povijesti izrade brodova jesu kalafati - majstori koji su davali svoj pečat i dušu - te su o umijeću majstorskog marifeta ovisile estetske i plovne karakteristike broda. Tradicija tvrdi da je brod „nov, sve dok ima drva u gori", da brod nadživi svoga tvorca, vlasnika i mornare (Salomon, 2009.).

U staroj drvenoj brodogradnji nije bilo detaljnih nacrta jer je svaki brodograditelj imao svoje tajne zanata, ali bilo je i nekih općih pravila i propisa kao što su: „Omjer duljine, širine i nacrta broda, odnosno dobre proporcije između duljine i širine jesu vrlo važni za brzinu broda" (Kalogjera,1998). Kalafati su osnovu zanata temeljili na alatima, teslici i blanji, dobrom drvu, oštrom oku i osjećaju za uklapanje ručno izrađenih elemenata u konstrukciju koja će na vodi imati prava svojstva: „držati“ more, prkositi valovima i plijeniti ljepotom. Dugogodišnje kalafatavanje, iskustvo u zanatu, iznjedrilo je tako i zabilježbe o vrstama drva koje su se upotrebljavale u izradi brodova, kao i o vremenu sječe te načinu pripreme drva za uporabu u tradicionalnoj brodogradnji (Salamon, 2016.).

Drvena se građa dugo i pažljivo pripremala, složena na hrpe i izložena vremenu, te je morala biti posve suha prije obrađivanja, a nadasve prije ugradnje u brodove. Oblikovanje, obrada i pričvršćivanje drva predstavljali su vještinu koja se strpljivošću i eksperimentiranjem usavršavala tijekom niza godina.

Pronađeni zapisani podaci kalafata ukazuju da je drvo najbolje sjeći „između dvije gospe: Gospe od Karmela i Vele Gospe ili u srid zime". Za donji dio broda, koji je pod morem, odabirali su ariš (Larix), hrast medunac (Quercus pubescens) i česminu (Quercusilex). Kalafati su uvijek imali na umu kako pripremiti drvo prije izrade broda pa su tako, ovisno o vrsti drva, znali kako i koliko ga močiti u moru da ožilavi, kako s njim postupati kad ga se izvadi na zrak iz mora prije obrade i ugradnje u brodove. Močenjem u moru izbjegavalo se kasnije raspucavanje drva. Istovremeno je to močenje u moru bilo i jedan od oblika konzerviranja drva (Radić, 2015.). Osim močenja u moru, prema pričama koje se prenose s generacije na generaciju (URL 3), pamti se da se netom „ubrano" drvo zakopavalo u gnjoj u zagonu kako bi se ono konzerviralo i da se ne bi prilikom sušenja raspucalo. No, može se reći da su kalafati znali svoj posao, iskustvo su prenosili s generacije na generaciju i tradicionalno su se koristili domaćim vrstama drva.

Do početka 19. stoljeća drvo je bilo jedini materijal koji se mogao jednostavno nabaviti te lako ručno obrađivati i oblikovati s pomoću jednostavnih alata. lako postoji puno vrsta drva, nisu sve jednako upotrebljive u brodogradnji. Čak unutar iste vrste drva mogu postojati značajne razlike koje ovise o klimatskim uvjetima gdje je drvo raslo (Leinenfost,1966.).

Česmina - crnika (Quercus ilex) koristila se za izradu kobilice, statve, rebara, ruda kormila i bitvi zbog toga što je vrlo trajno, teško, tvrdo, čvrsto i elastično drvo. Teško se obrađuje i sklono je raspucavanju ako nije postupno prosušeno nakon duljeg ležanja u moru. Suho obrađeno drvo bora (Pinus nigra, Pinus maritima, Pinus hallepensis, Pinus silvestris) pililo se, blanjalo i zaobljavalo za gradnju drvenih brodova. Iskonsko dalmatinsko brodovlje „počivalo je na vonju bora“. Lagano, čvrsto i otporno drvo omogućavalo je i zahtjevnije izrade. Kombinacijom crnog bora, tvrđeg, s primorskim (Pinus pinaster) i alepskim borom (Pinus halepensis) moglo se izraditi i cijelo plovilo, ali se najčešće koristio za jarbole.

Žitelji otoka Vrgade kažu da je od bora najbolje izraditi one dijelove broda koji su iznad morske vode, dok Korčulani smatraju da je borovina najbolja za madire i korbe jer dobro podnose paljenje, tj. krivljenje drva na vatri, u hodu, u težnji za idealnim oblikom te anatomskim ugrađivanjem u tijelo broda.

Osim za izradu drvenih dijelova broda, borovina je prihvatljiva i zbog svoje smole, koja se koristila za kuhanje zajedno s katranom u kotlu na otvorenoj vatri, kako bi se dobila paklina/pakal/pakol. Tom su se smjesom premazivali drveni brodovi izvana, madiri i stupa koja ide između njih, da bi se spriječio prodor morske vode $u$ unutrašnjost broda.

Uz navedene vrste drva, u izgradnji brodova na jadranskoj obali, zbog svojih svojstava trajnosti, čvrstoće, elastičnosti i lake obrade, hrastovina je vrlo zastupljena za izradu svih važnijih konstruktivnih elemenata, od rebara, kobilice i razme do statve, s naglaskom na hrast medunac (Quercus pubescens) za izradu zakrivljenih dijelova broda.

Jedrenjaci su imali pramčane ukrase - pulene i oči tipične za trabakul, izrađene od murve - duda (Morus alba) jer je drvo posebno čvrsto, trajno i dobro se održava u vodi.

Stjecajem okolnosti naši su brodovi građeni u prijašnjim stoljećima od visokokvalitetnog hrasta. Zbog te činjenice trajnost naših brodova nekoliko je puta veća od drugih. Ta je činjenica, a ne sustavna briga o njima, ujedno i jedini razlog da svi ti brodovi još plove.

\section{TRABAKULI / Trabaccolos}

Među ponuđenim temama posebnu pozornost privlače zanimljivosti vezane za stogodišnje drvene tradicijske brodove koji su još u funkciji i plove Jadranskim morem. Održavanje takvih brodova zahtijeva posebne vještine i znanje, a njihovim prenošenjem održava se povijesni kontekst očuvanja kulturne baštine i u tradicionalnoj brodogradnji. Od sredine 18. do kraja 20. stoljeća na Jadranskome moru i istočne i zapadne obale razvijen je drveni brod s pogonom, propulzijom na vjetar pod imenom trabakul (Bernardi, 1975.).

Trabakul (trabakula, trabakuo), izvedenica od arapske riječi tabaqah ('krov'), naziv je za dvojarbolni tradicionalni obalni, teretni jedrenjak na istočnoj obali Jadrana (Slika 1). Inačica je malog broda hrvatske obale Jadrana, napravljen da izdrži veću dinamiku mora, istodobno prevozeći veću količinu tereta. Upotrebljavao se isključivo za trgovinu, ribarstvo te prijevoz ljudi i tereta (Karabaić, 1989.).

Trabakuli su u upotrebi od 18. do početka 20. stoljeća. Trup mu je pun i zaobljen, zdepasta oblika, a pramac i krma jajoliko-šiljastog oblika na nadzvođu završavaju tupo. Pramčana i krmena statva lučno su zakrivljene prema unutrašnjosti broda. Dug je 14 - $30 \mathrm{~m}$, širok 3,5 - $6 \mathrm{~m}$, visok 1,5-2,5 m i nosivosti $40-200 \mathrm{t}$ te ima od četiri do osam članova posade (Vidan, 2012.).

Za dublje more i teže uvjete plovidbe duž istočne jadranske obale gradio se umjereno zaobljena dna i uzvoja s umjerenim gazom, dok se za plovidbu plićim morem, uvalama i zaljevima sjevernoga Jadrana gradio gotovo ravna dna i zaokruženih bokova, s naglim prijelazom dna u bokove, malim gazom te jakim 
zaobljenjem pramca i krme. Paluba se pružala cijelom duljinom broda, a neke su izvedbe imale i jedan veći otvor grotla među jarbolima, kroz koji se ukrcavao i iskrcavao teret. Na pramcu i krmi bile su i dvije manje prostorije za smještaj članova posade (Kozličić,1993.).

Stast se sastoji od dvaju jarbola, usađena na $1 / 4$ i 3/4 duljine, postavljena najednakim udaljenostima između krmene i pramčane statve, na kojima su se razapinjala dva oglavna jedra, pričvršćena na dvjema oblicama, te dug kosnik na pramcu za razapinjanje ljetnog jedra, kojemu je vrh bio pričvršćen za pramčani jarbol. Jedra su isprva bila oglavna, kasnije je krmeno postalo sošno, a zatim su oba bila sošna. Oglavna jedra trabakula, specifična oblika, nazivala su se i trabakulnim jedrima (Mardešić, 1972.).

U 18. i 19. stoljeću upotrebljavalo se i po jedno posrtno jedro u području kosnika. Jedra su izrađena u jednom komadu. Izrezbareno i ukrašeno dugačko rudo kormila (argola) dosezalo je gotovo do krmenoga jarbola, kako bi se moglo upravljati s veće udaljenosti (Dvornik, 2013.).

Kormilo seže duboko ispod kobilice, čemu je svrha onemogućivanje zanošenja broda. Na palubi ima bitve za privez, a sidro se dizalo motovilom ili sohom. Ima ulaze u pramčani i krmeni prostor, a na sredini veliko grotlo skladišta. Pramčana statva završava jabukom koja je nerijetko modelirana u obliku ljudske glave i povijena unazad. Na pramcu ima oči kao ukras, a ispod njih otvore za sidrene lance. Po sredini je broda veći otvor za krcanje tereta, dug do jedne petine duljine broda.

Trabakul je prekriven neprekinutom palubom koja se diže od sredine prema pramcu i krmi, ali tako da je pramac viši od krme. Ograda je visoka oko pola metra. Ima dva dvokraka i jedno pričuvno dvo- ili četvrerokrako sidro (Bernardi, 1975.).

Za trabakule kaže se da iako su manji jedrenjaci, nemaju ništa s romantikom i izgledom, već je u njih važna surova snaga za borbu s visokim valovima i divljim vjetrom (Kozličić, 1993.).

Trabakul se u ono vrijeme vrednovao kao brod niske cijene izrade s dobrim pomorskim svojstvima. Pomorci Jadrana davali su mu prednost u odnosu na suvremenije tipove velebnih jedrenjaka elegantnijih linija, zahvaljujući njegovim svojstvima nabrojenima u nizu: mali gaz, dobra stabilnost u uvjetima različitog stanja natovarenosti, dobra manevarska svojstva, lako održavanje i mogućnost karinjenja (naginjanje na jedan bok da bi se obavili radovi održavanja na drugom), jedrenje bez balasta i u stanju bez tereta, umjereno ljuljanje i posrtanje, zadovoljavajuća brzina, veliki kapacitet krcanja tereta u odnosu na veličinu broda te mali troškovi izrade trupa i opremanja (Bernardi, 1975.).

\section{TRABAKUL SVETI IVAN / Trabaccolo St John}

Kako je na početku rada spomenuto, jedan od najstarijih trabakula koji i danas plovi Jadranskim morem jest trabakul Sveti Ivan, izgrađen 1878. u Ladjedjelnici Piran obitelji Apollonio. To je industrijsko poduzeće osnovano 22. listopada 1954. u Piranu. Brodogradilište se u Piranu spominje već u gradskom Statutu 1322., a u doba Mletačke Republike pripadalo je državi. Oko sredine 19. stoljeća postojala su na području Bernardina kraj Pirana brodogradilišta A. Apollonija, A. Dapretta i L. Bontempa, poslije i grofova Furegoni, u kojima su se gradili drveni ribarski i trgovački brodovi za obalnu plovidbu za mjesne naručitelje (Marinac, 1997.).

U to se vrijeme brod koristio za prijevoz ulja i vina po jadranskoj obali, kasnije za prijevoz raznih tereta, a ponajviše pijeska. Zbog toga nosi naziv salbunjer ili sabunar.

Trabakul Sveti Ivan je do danas sačuvanog tradicionalnog izgleda, uz napomenu da je od 1996. prenamijenjen i služi za prijevoz turista dubrovačkim akvatorijem. Zanimljiv je za sve turiste koji dođu u Dubrovnik, a posebno za one koji uživaju ploveći jednim takvim starim tradicionalnim brodom oko povijesne jezgre. Moglo bi se reći da brod dvostruko pridonosi turističkoj ponudi grada, jedne od vodećih turističkih destinacija svijeta, samim time što turisti mogu biti na brodu starom više od jednog stoljeća i pritom uživati u ljepotama zidina kojima je opasan stari dio grada Dubrovnika.

Sveti Ivan je obalni jedrenjak sličan braceri, ali većih dimenzija, dužine 13,2 m i širine 5,2 m s dvama jarbolima. Trup je oblih bokova i oblog dna s kobilicom (Slika 3. i 4.). Oblik pramca i krme jest jajoliko-šiljast. Kormilo mu seže duboko ispod kobilice. Dva jarbola sastavljena su od jednog komada drva, mogu imati nastavke na koje ne dolaze jedra (Slika 2.). Pramčani jarbol veći je od krmenog. Na obama jarbolima ima oglavna jedra, obično s tri ruke kratica.

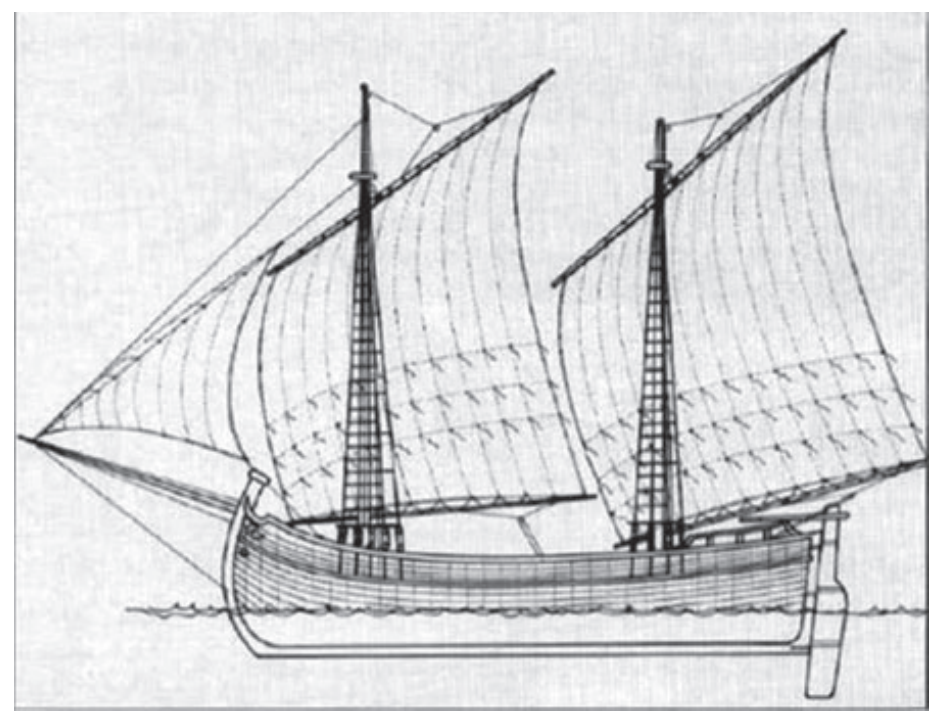

Slika 1. Hrvatski trabakul

Figure 1 Croatian trabaccolo 

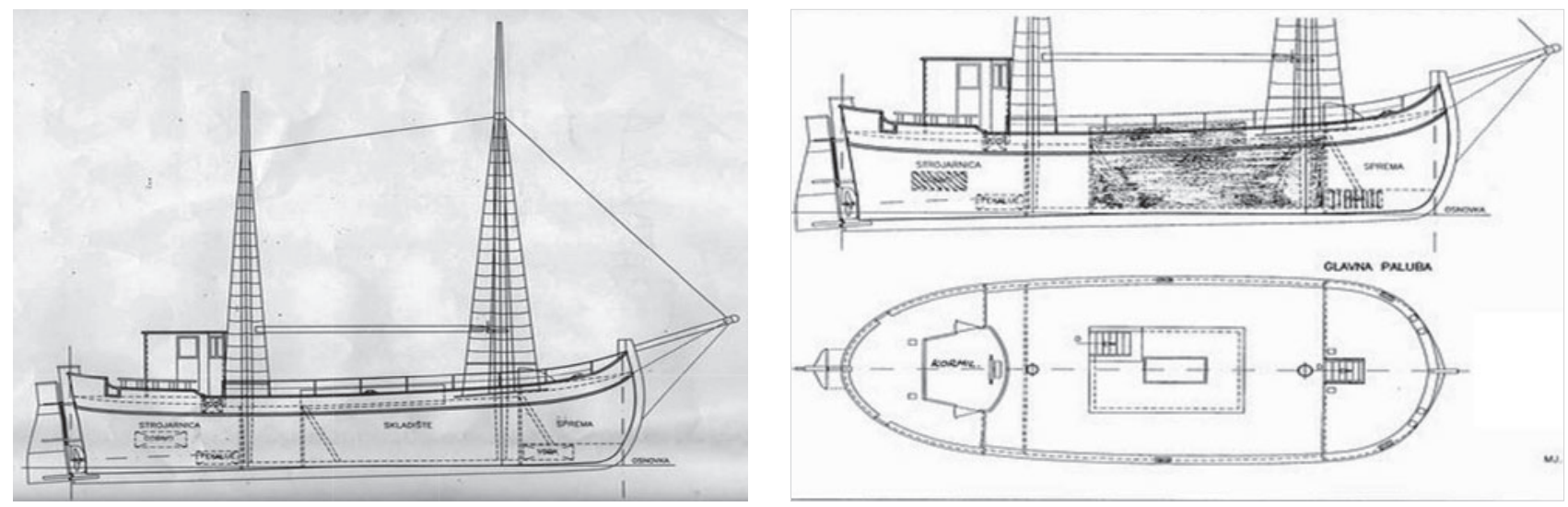

Slika 2. i 3. Sveti Ivan 1999.

Figure 2 \& 3 St John 1999

Izvor: Proračun stabiliteta m/b Sv. Ivan, 2002.

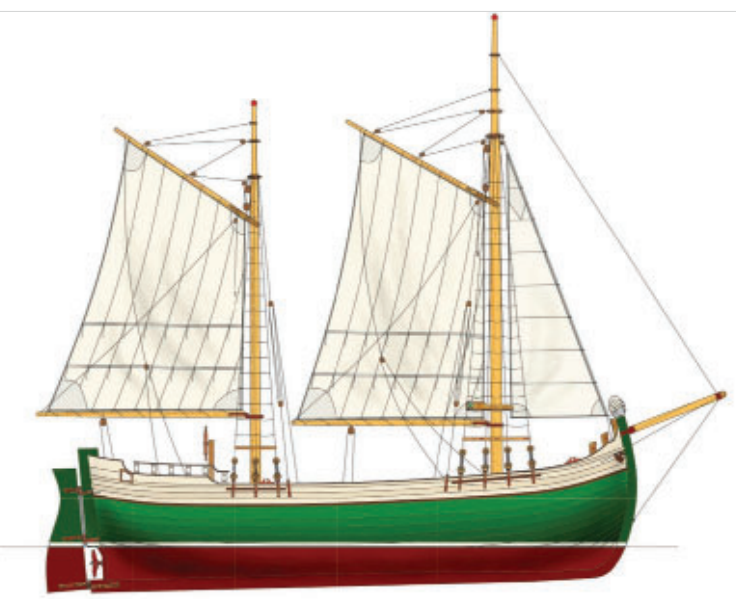

Slika 4. Sveti Ivan 2002.

Figure 4 St John 2002

Izvor: Nenad Bojmić

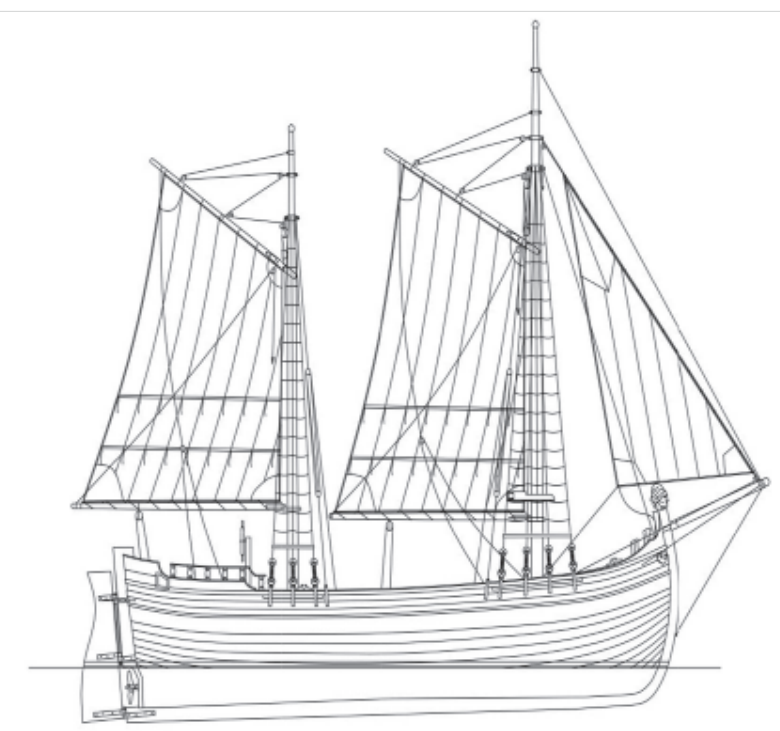

Slika 5. Sveti Ivan (flok)

Figure 5 St John (jib)

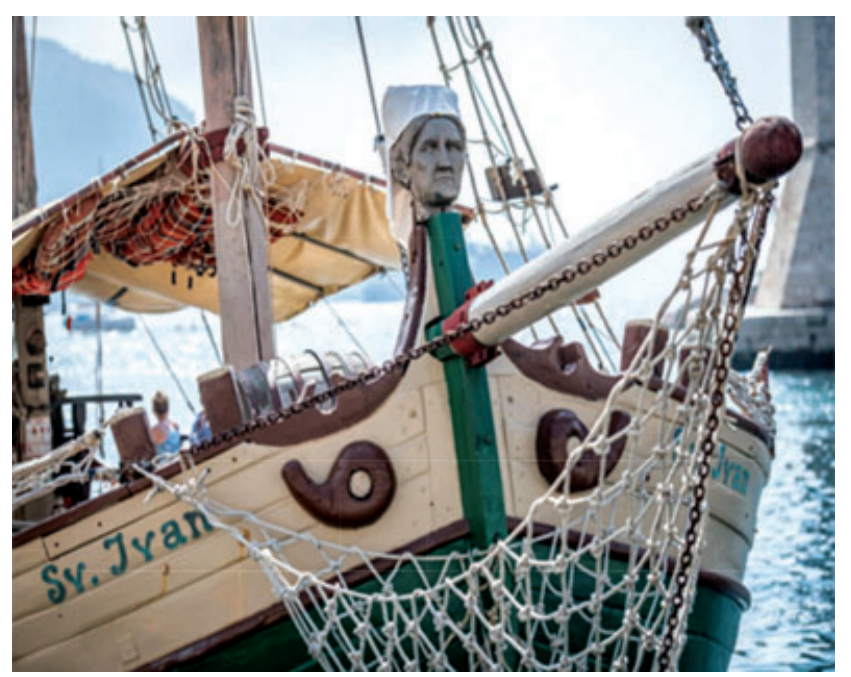

Slika 6. Pramac

Figure 6 Bow

Izvor: M. Bego

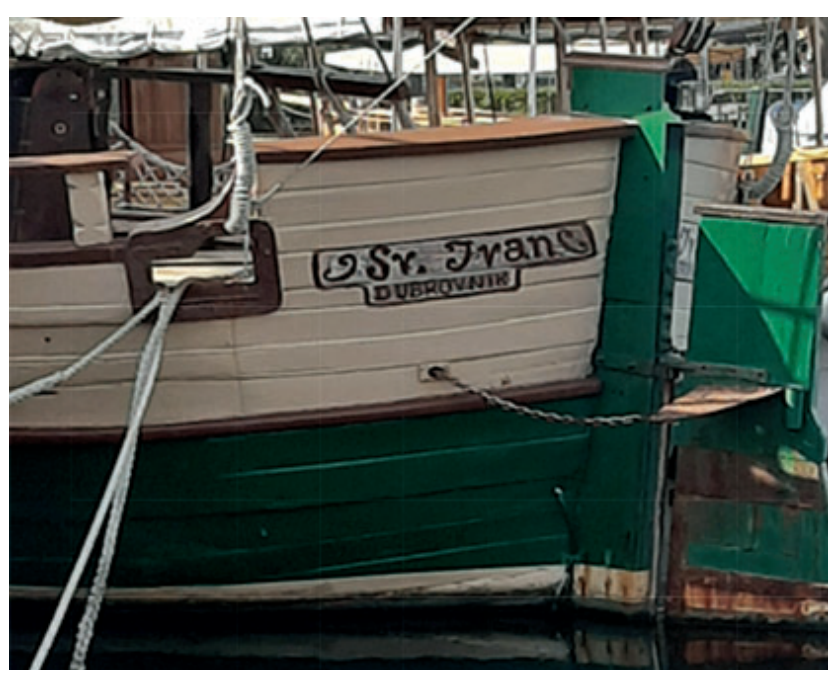

Slika 7. Krma

Figure 7 Stern

Izvor: M. Bego 
Drveni konstruktivni dijelovi broda Sveti Ivan izrađeni su od više vrsta drva. Mora se naglasiti da je sadašnje stanje trupa broda više od $85 \%$ originalno iz godine izgradnje, što je vrlo važno u kontekstu kad se govori o najstarijem plovećem brodu na Jadranskom moru.

Na brodu je pramčana figura-pulen iz 2001., izrađena od murve, koja predstavlja baku sadašnjih vlasnika broda, Nina i Mara Kovačevića. Do 1996. brod je bio u vlasništvu obitelji Rakuljić, do kada je imao originalni pramčani ukras, kasnije poklonjen muzeju. Osim pramčanog ukrasa, svaki trabakul, pa tako i Sveti Ivan, na pramčanom dijelu broda ima oči kao ukras (Slika 2.).

Kobilica, kolumba, napravljena je od dubovine (prema lokalnom nazivu), dalmatinskog hrasta/česmine/hrasta crnike (Quercus llex), dužine $13 \mathrm{~m}$, debljine $45 \mathrm{~cm}$ i širine $17 \mathrm{~cm}$. Bitve, privez, naziva i „pašilek“ zijevalice su izgrađene također od česmine. Za izradu madiera koristila se borovina i hrastovina, ovisno o masi broda, ali ipak najčešće hrastovina jer bi se borovina na težinu od 37 tona "ugnječivala".

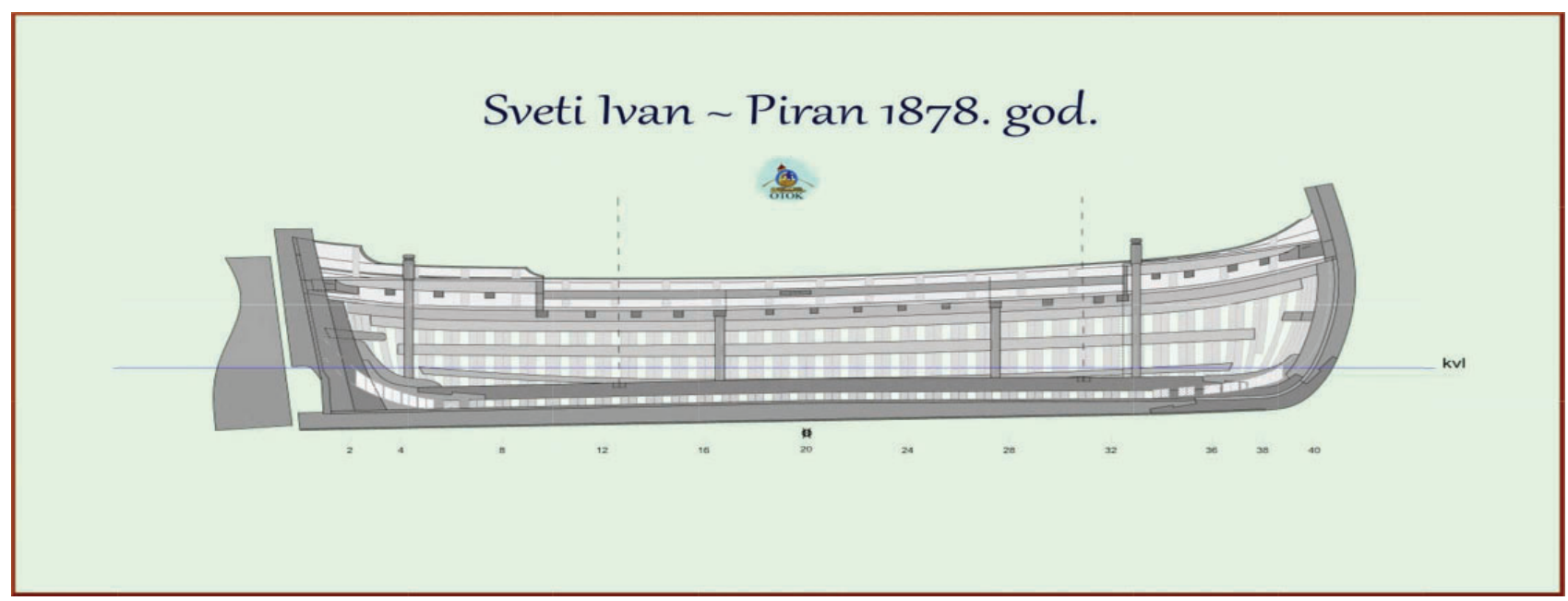

Slika 8. Presjek trabakula

Izvor: Nenad Bojmić

Figure 8 Cross section of the trabaccolo
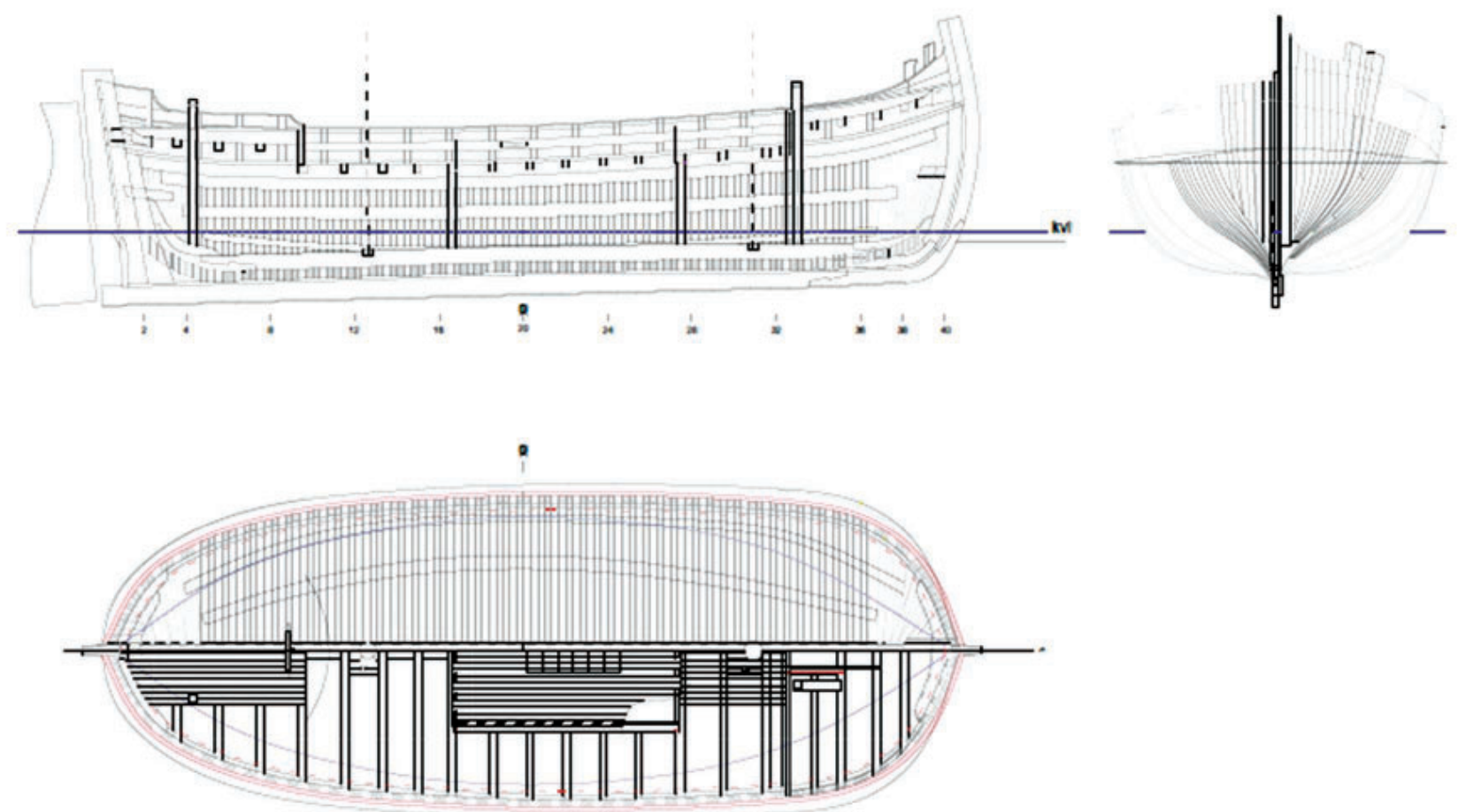

Slika 9. Konstrukcijski prikaz trabakula Sveti Ivan

Figure 9 Construction of the trabaccolo St John

Izvor: Nenad Bojmić 


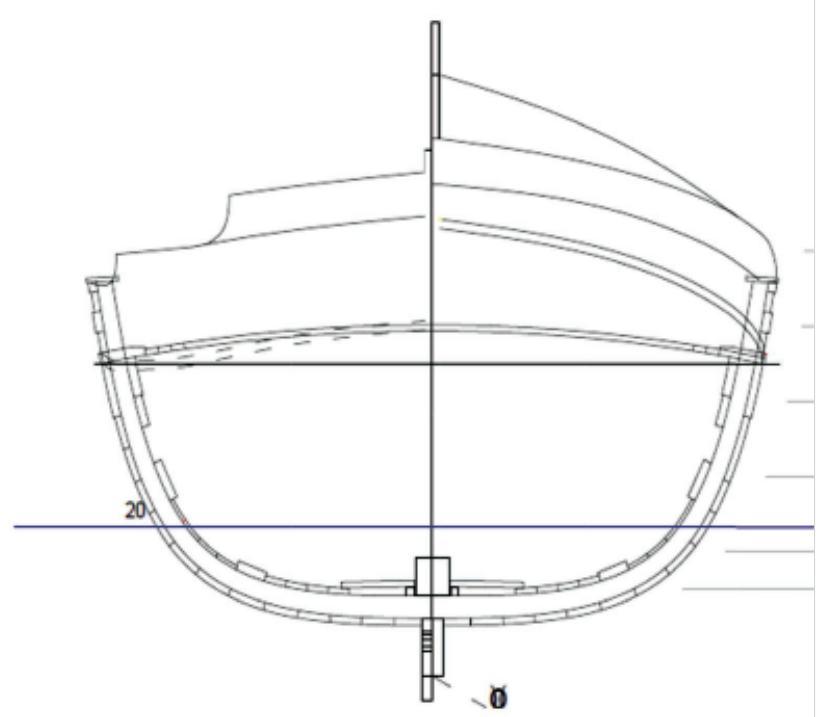

Slika 10. Glavno rebro Figure 10 Main frame

Izvor: Nenad Bojmić

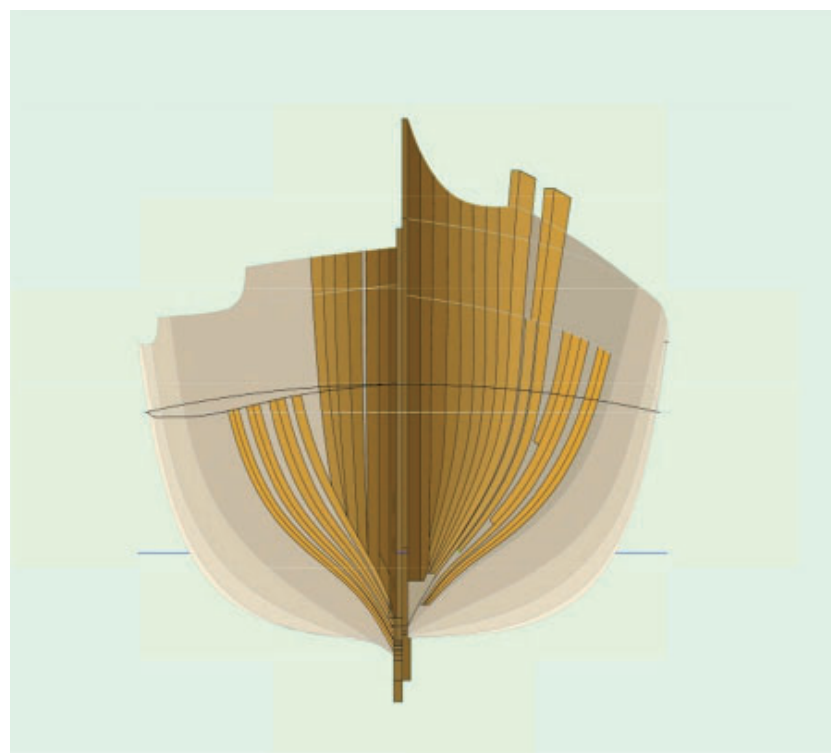

Slika 11. Radijalna os

Figure 11 Radial axis

Izvor: Nenad Bojmić

Korbe, rebra, bila su izvorno izgrađena od murve ili duda (Morus), da bi se kasnije mijenjale u hrastove korbe, debljine od 12 do $15 \mathrm{~cm}$.

Spajanje se izvodilo galvaniziranjem čavline, pri čemu bi se dodavao "češ" zbog mogućeg propadanja čavla. Koristili su se i drveni špinjeli (spin-igla) (Slika 9.).

Provena i krmena „aštva“ izrađene su od hrastovine. Kontramadieri, hrastove povezice s unutarnje strane broda, napravljene su tesanjem drvenih oblika ili zakrivljenjem drva (Slika 11.).

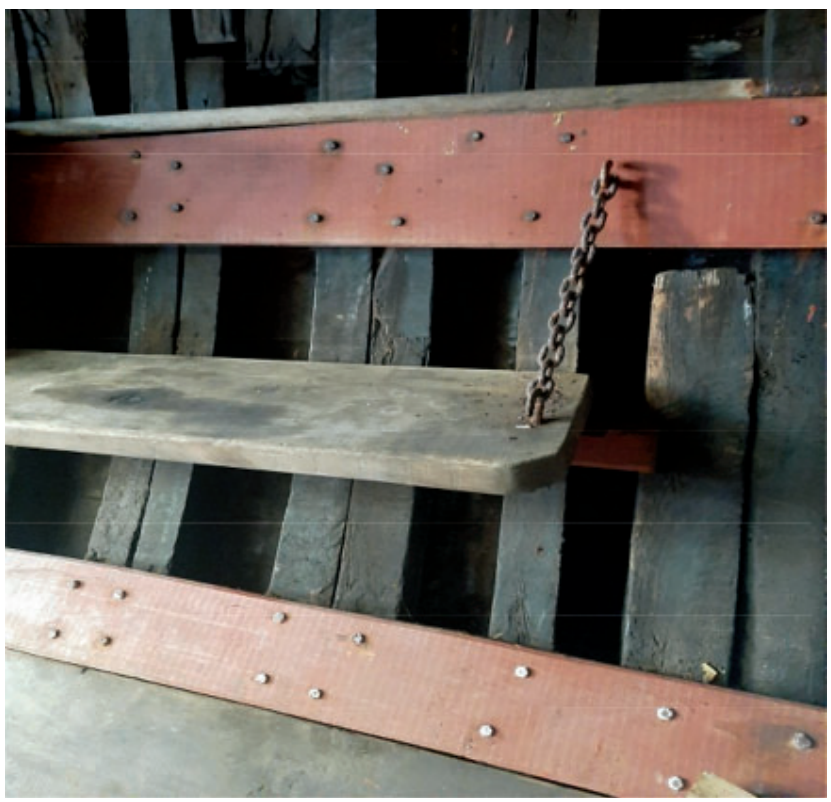

Slika 12. Unutrašnja bočna strana Figure 12 Inner hull planking

Izvor: M. Bego

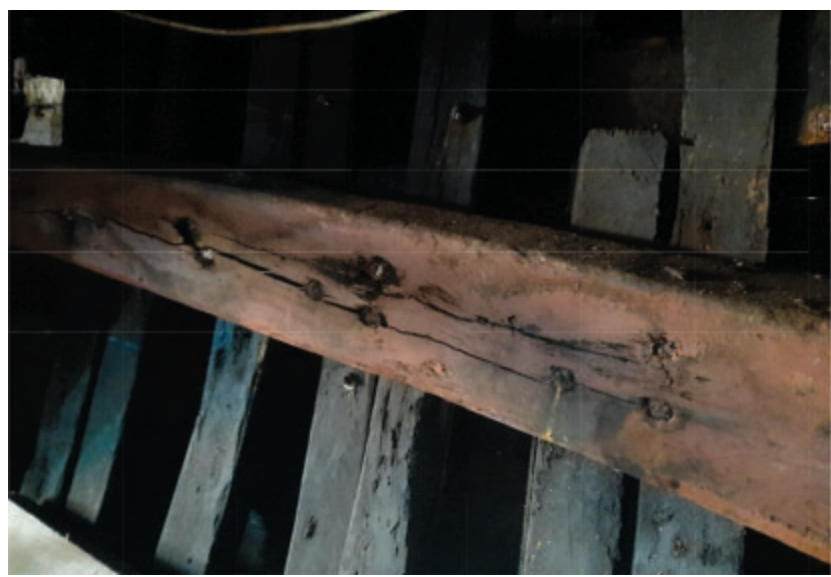

Slika 13. Dijelovi drvenog broda i način spajanja

Figure 13 Parts of the wooden ship and methods of connection Izvor: M. Bego

Parmezal, kontra kolumba, kobilica, izrađena je od hrastovine, širine $25 \mathrm{~cm}$, visine $25 \mathrm{~cm}$, poveznica kolumbe i korbi, kroz koje idu pasajice, promjera $22 \mathrm{~mm}$, od kovanog željeza.

Paluba broda, kuvierta, napravljena je od ariša (Larix), dužine $5 \mathrm{~m}$, širine $10 \mathrm{~cm}$ i debljine $4 \mathrm{~cm}$. Zanimljivo je, između ostalog, da se paluba zadihtavala pamučnjakom, pamučnim konopom, uz neophodno redovito zalijevanje morem, čime se stalno održavala vlaga i zbog čega je paluba ostala nepropusna, gdje je sol iz mora služila i kao sredstvo za konzerviranje drva zapunjavanjem pora na površini.

Dihtavanje broda jako je važno, poznavajući sva svojstva masivnog drva u uvjetima u kojima se brod neprestano nalazio i imajući na umu njegove karakteristike teretnog broda, pri čemu se velikim dijelom nalazio ispod površine mora dok je bio 


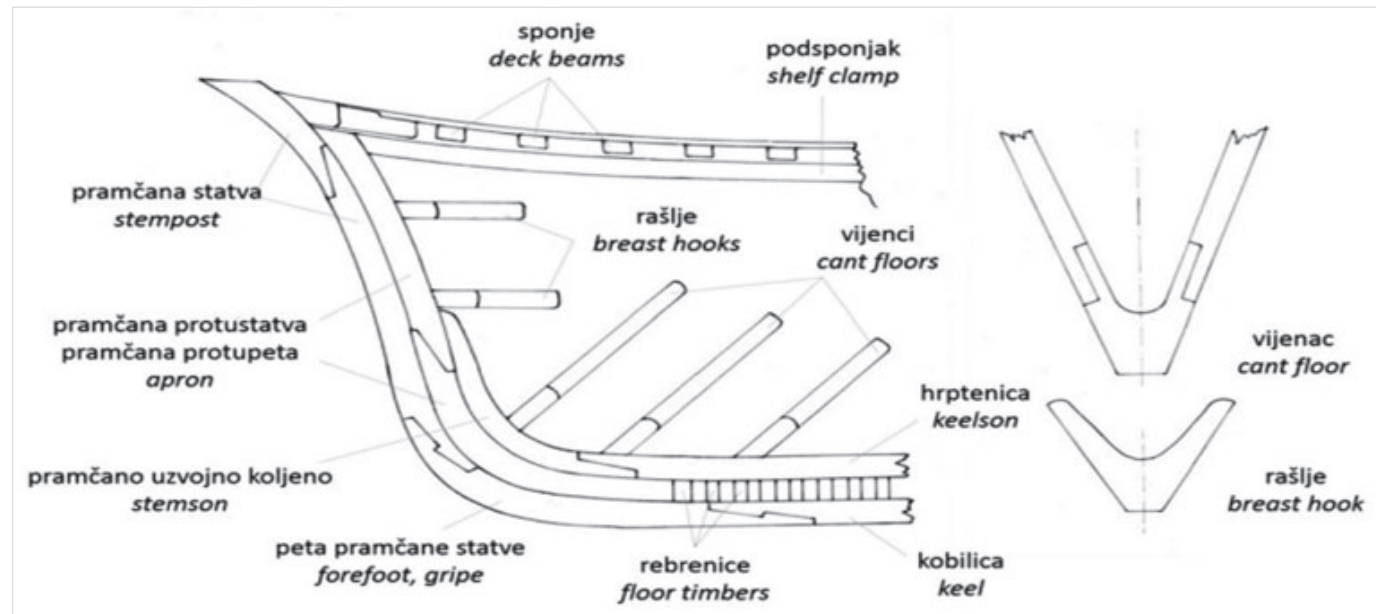

Slika 15. Uzdužni presjek pramčanog dijela broda (prema T. Bernardi, 1964., SI. 130.-132.)

Figure 15 Longitudinal section of the ship's bow (according to T. Bernardi, 1964, Fig. 130-132)

Izvor: I. Radić Rossi, 2015

nakrcan teretom. Klasično kalafatavanje s upletenom stupom, pomiješano s lanenim uljem, sprečava ulazak biše (morski insekti) u podvodnom dijelu broda.

Vanjska zaštita drva izvodi se tako što se površinski na spaljeno drvo nanosi „na vruće“ temeljni premaz, koji ulazi u površinske slojeve drva jer se nanosi u vrlo tekućem (rijetkom) obliku, stoga se nakon nanošenja stvori vrlo tanak sloj, sasvim nevidljiv. Potom se ponavlja postupak s temeljnim premazom, a zatim se nanosi uljana boja, pomiješana s lanenim uljem. Boja se nanosi u trima slojevima, što predstavlja zaštitu drvenih dijelova za jednu godinu. Zanimljivo je da se prije pronalaska novih bojila i lakova repariranje obavljalo tako da se drvo, koje je inače stalno pod vodom, tretiralo i mazalo „na vruće“ paklinom, što bi u današnje vrijeme predstavljalo postupke impregnacije drva.

„Brodovi bi se karinavali preko bucijela, kolumba, jarbola, natezali prema rivi, ali se ne bi vukli vani, nego bi se naginjalikarinan. Brod bi se ostavio par dana tako nagnut da se osuši, potom bi se palio površinski i na tako toplo drvo bi se mazalo smolom". Danas se u tu svrhu koristi premaz koper s bakrenim oksidom, da se spriječi napad morskih štetnika i školjki.

Drvo se „krivilo“, odnosno savijalo s pomoću vodene pare i kuhanjem. Prilikom paljenja drvo se premazivalo lojem kako bi se spriječilo pucanje prilikom savijanja i iskrivljenja, gdje bi se potom stavljale mokre krpe da se smanji mogućnost pucanja drva. Iz navedenog može se zaključiti da je možda jedan od razloga zbog kojeg je i danas brod u dobrom stanju tradicionalna površinska obrada, odnosno zaštita i održavanje drva na ugrađenim drvenim dijelovima, izrađenima od masivnog drva.

Trabakul Sveti Ivan ima dva jarbola napravljena od ariša (Larix), uz napomenu da su se jarboli izrađivali još od čempresa (Cupressus sempervirens $\mathrm{L}$ ). Jarboli su se utezali s provene strane, što je do pojave sajli bio debeli konop po kojem se podizalo jedro preko mesinganih karabina, „gambeta“. S bočnih je strana jarbol utegnut s 3 - 4 konopa koji se zovu "sartije“, a natezali su se preko „bigota“ jer su se konopi zbog otpora vjetra otezali. Na gornjem dijelu jarbola postavljena su dva „patarca“, koja se zatežu u suprotnu stranu vjetra da spriječe lom jarbola. Između satija „pjombavale" su se skale od konopa, za penjanje na jarbol. Na krmenom jarbolu sve je isto kao i u provenog. Na pramcu nalazi se olujni flok.

Jedra su na brodu sošna, sastavljena od buma i soške, izrađena od tele, impregnirana voskom i opšivena na konope. Podižu se s pomoću bucijela, koloturnika.

Brod je do 1920. plovio isključivo na jedra, a nakon toga ugrađen mu je motor, Testa calda, vruća glava, snage $10 \mathrm{KS}$, koji se palio ručno. Prije samog paljenja glava motora morala se ugrijati plamenikom, da se postigne temperatura paljenja. Motor nije imao kopču za naprijed-nazad, nego se morao ugasiti pa zatim ponovno upaliti za kretanje u suprotnu stranu. Brzina je motora 4 - 5 nautičkih milja.

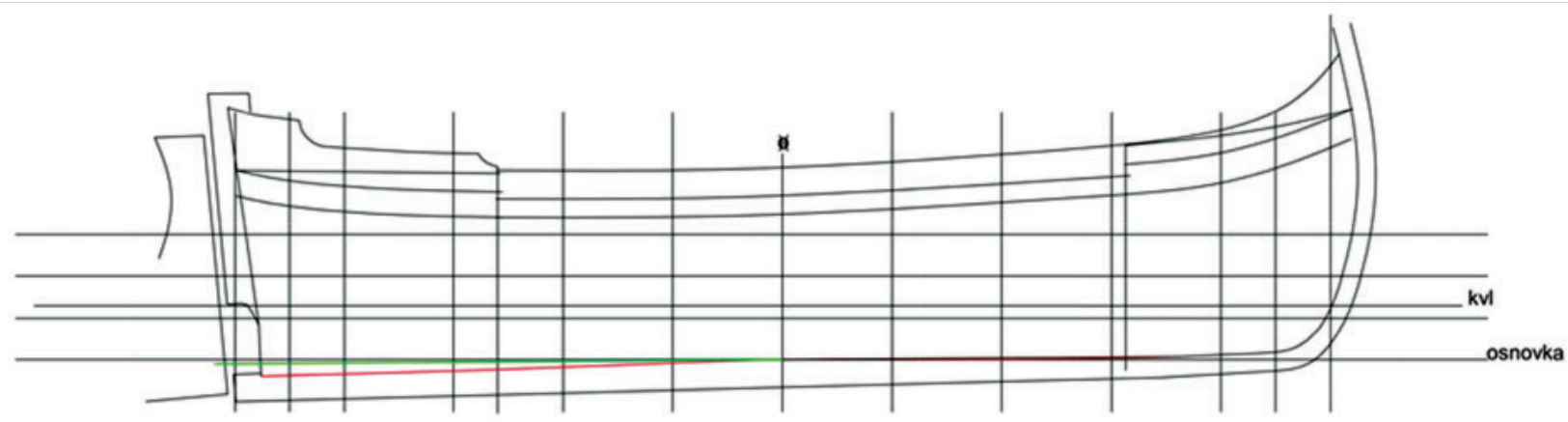

Slika 16. Osnovne linije broda Figure 16 Main lines of the ship 
Slika 16. prikazuje vidljivu konstrukcijsku izmijenjenu liniju dna broda i kobilice. Ugradnjom motora 1920. bilo je potrebno stvoriti odgovarajući izlaz osovine i prostor za propeler. Od središnjeg rebra vidljiv je lom linije, označen crvenom bojom, u odnosu na prvobitno stanje, označeno zelenom linijom.

Kao što se dade iščitati, brod je prepun zanimljivih originalnih dijelova, od kojih bi se mogle napraviti i zasebne priče, koje bi se kao takve mogle koristiti i tiskati u promotivne svrhe prilikom svake plovidbe.
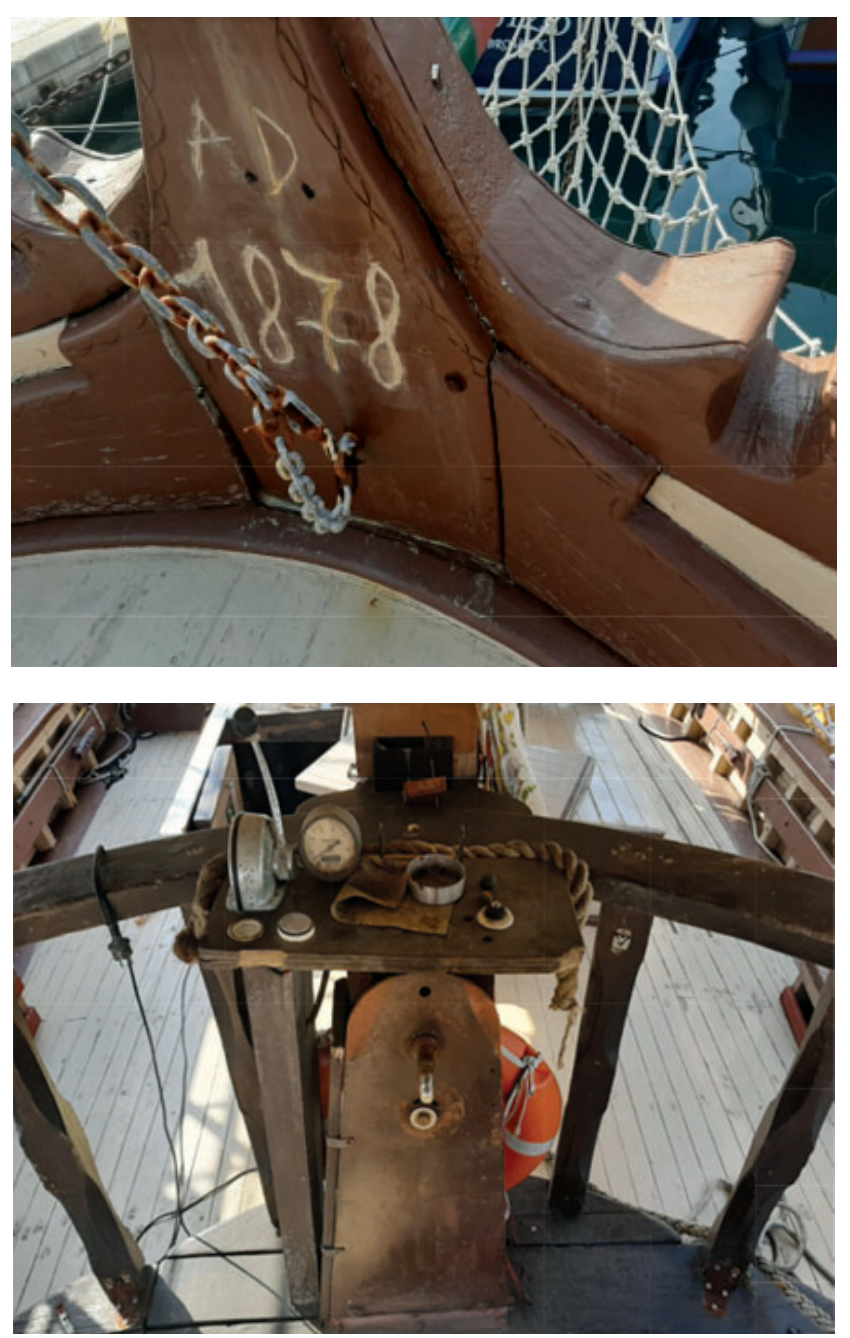

Slika 17. i 18. Detalji pramčanog dijela drvenog trabakula Sveti Ivan i upravljački most

Figure 17 \& 18 Details of the bow of the wooden trabaccolo St John and navigating bridge

Izvor: Margarita Bego-Urban

U radu vidljivo je bogatstvo riječi koje nisu svima poznate $i$ razumljive pa će kratak rječnik tradicionalnih pojmova olakšati razumijevanje i čitanje rada.

\section{Rječnik tradicionalnih pojmova u radu kojima se koriste kalafati i vlasnici starih drvenih brodova:}

argola - poluga na kormilu; drvena horizontalna drška kormila, rudo; poluga kojom se okreće kormilo

ašta - provena i krmena statva; produžetak kolumbe na provi i krmi; statva na provi ili krmi broda; nastavak kobilice na kraju pramca ili krme bigota - drveni plosnati valjak, promjera $13 \mathrm{~cm}$, debljine $5 \mathrm{~cm}$, s 3 - 4 rupe, služi za natezanje sartija ili pripona (sarče-tornoali) koje drže jarbol na brodu; danas su ih zamijenili tiranti (stezalice) od prokroma, dead eye ('mrtvo oko')

bitva - kratki kameni ili željezni stup na mulu za privez broda, kazuk, kolona; drveni stupić na brodu za koji se veže konopac, mankul; stupić na brodu ili kopnu koji služi za privez broda; u sredini prove za vezivanje

biša - crvotočina na brodu

bucijel - bucio, bucel, koloturnik, kotač, na čijem je obodu urezan žlijeb za konop, za lakše podizanje tereta

češ - podložak koji se stavlja ispod čavla da onemogući propadanje u rupu

dihtovanje - umetanje stupe ili pamučnjaka između drva zbog nepropusnosti

drveni špinjel - štapići za popunjavanje rupa od čavala

gambet - spojnica između sidra i sidrenog lanca

galvaniziranje čavline - tretiranje čavla cinkom

kalafat - kalafot, brodograditelj drvenih brodova; drvodjelac koji izrađuje brodove; brodograditelj drvenih brodova, majstor drvodjelac koji gradi brodove (prvotno zanatlija koji smolu i kučinu zabija između madira broda te u spojeve drvenih dijelova i tako ih međusobno brtvi)

kalafatavanje - učiniti dno broda nepropusnim, zatvoriti smolom i kučinom šupljine te spojeve drvenih dijelova broda

karinavanje - čišćenje dna broda dok je nagnut na jednu stranu katarka - drveni stup na koji se razapinju jedra

kobilica - masivna greda, glavni uzdužni element brodske konstrukcije

kolumba - debela uzdužna greda na dnu broda na koju se naslanjaju rebra

kontra kolumba - paramezal

korba - rebro na brodskom skeletu koje se nastavlja na kolumbu od dna broda

kuvijerta - brodska paluba

madijera - vanjska brodska daska pribijena uz rebra broda, drvena oplata za brod

marifet - majstorsko umijeće, spretnost, umjetnost

motovilo - komad drva ili pluta za namatanje konopca ili tunje pajuli - daska ili više njih kojima je prekriveno brodsko dno i lokoče; drvena podna daska (podnica) čamca ili broda; pomična drvena podnica broda, daske za pokrivanje dna broda paklina - pakal, pakol, borova smola kao zaštitni premaz za brod, pegula; mazalo se podvodni dio brodske oplate i spojeve madira

paramezal - povezice kolumbe i korbi

pasajice - dugi čavao za spajanje rebara u brodu ili barci patarac - leteća zaputka, vrsta krmenog štraja u paru, s jarbola na krmu, za lijevu i desnu stranu, jedan u funkciji ovisno o uzdama (položaju gl. jedra)

pjombat - pjombavati, upletanje, sastavljanje dvaju krajeva konopa

salbunjer ili salbunar - brod za vađenje i prijevoz pijeska sartija - konopi na brodu koji drže katarke, na čijim se krajevima nalazi drveni kotač, bigota

statva - dio brodskog trupa kojim završava kobilica

stupa - kučina koja se nabijala u kimente prilikom stupanja verzine - u većih brodova unutarnji madir pri dnu koji povezuje sve glave; na verzinu mogu se oslanjati pajoli 
vonj-miris

zijevalice - drveni ili željezni žlijeb na ogradi broda kroz koji se privlače konopi

Izvori: Benčić, 2013; Braica, 2015; Stolac, 1988; Bego-Urban, 2010

\section{RASPRAVA I ZAKLJUČAK / Discussion and conclusion}

Jedan od najstarijih brodova na Jadranu koji još uvijek plovi dubrovačkim arhipelagom jest trabakul Sveti Ivan, izgrađen prije gotovo stoljeća i pol. Koristio se kao manji teretni jedrenjak za prijevoz ulja i vina, a kasnije pijeska, po čemu je dobio naziv salbunjer. Trabakul je izgrađen od masivnog drva hrasta, česmine, duda, ariša i bora. Dijelovi su broda tesani i zagrijavanjem zakrivljeni. Zbog mogućeg prodora mora, dio koji je najčešće ispod površine dihtovan je pamučnjakom potopljenim u laneno ulje. Površinski dijelovi trabakula zaštićeni su tradicionalnim metodama paljenja i nanošenja pakline, što je danas zamijenjeno nanošenjem zaštite temeljne boje $s$ lanenim uljem u vrlo rijetkom obliku koji se nanosi višeslojno, stvarajući tanak film na površini. Trabakul s dvama jarbolima koji su ga pogonili do 1920. danas plovi s pomoću motora s ručnim paljenjem, koji se zagrijava plamenikom da bi se postigla temperatura paljenja. Drveni su dijelovi broda $85 \%$ i danas u izvornoj izradi tradicionalnim kalafatavanjem, što ga čini vrlo zanimljivim i posebnim. Osim svih zanimljivosti vezanih za drvene brodove izgrađene prije nešto više od stoljeća i pol, zanimljivi su pojmovi i izrazi kojima su se koristili kalafati $i$ vlasnici drvenih brodova tijekom godina i stoljeća, a koji su se u originalnim izrekama održali do danas duž jadranske obale, ostavljajući budućim generacijama bogatstvo govora i izraza.

Znanje, vještine i umijeće kalafata od neprocjenjive je važnosti za očuvanje i održavanje stoljetnih drvenih brodova, uz poznavanje tradicionalnih metoda pripreme i održavanja drvenih elemenata od kojih su ti brodovi izrađeni. Teško da takvo tradicionalno rukovanje alatima i odabir materijala može zamijeniti moderna tehnologija. Potrebno je obrazovati i poticati nove generacije na ustrajnost u očuvanju vještina i znanja radi što dužog opstanka drvenih brodova u plovidbi duž jadranske obale, promovirajući pritom dugogodišnju tradiciju izrade drvenih brodova.

Bogatstvo kulturne baštine Republike Hrvatske vidljivo je u mnogim segmentima, što omogućuje i zahtijeva od ljudi svih profila - stolara, restauratora, kalafata, povjesničara umjetnosti i znanstvenika - da upotrijebe svoje znanje i vještine kojima se naslijeđeno bogatstvo čuva i dalje prenosi na stanovnike i turiste, učeći povijest, običaje i način života ljudi određenoga geografskog područja. Trabakul Sveti Ivan je jedan od najstarijih drvenih brodova na Jadranu koji i dalje plovi. A plovi dubrovačkim akvatorijem u 21.-om stoljeću u turističke svrhe i izvrstan je promotor drevnog grada Dubrovnika, koji je u svojoj bogatoj prošlosti imao jaku pomorsku, osobito, trgovačku flotu. Vrlo je zanimljivo i naglasiti da je na primjeru trabakula Sveti Ivan prikazana i važnost zanimanja kalafata koji su stoljećima, prenoseći svoja znanja i vještine održavali bogatu tradiciju izrade drvenih brodova te plovili kroz povijest sve do današnjih dana Jadranskim morem.
Imajući na umu sve prednosti moderne tehnologije i materijala, može se zaključiti da tradicionalne vještine bez kojih ne bi bilo moguće izgraditi jedan drveni brod nikad neće pasti u zaborav. Svakako treba naglasiti da postoje mnoge zanimljivosti povezane s izradom tradicionalnih drvenih brodova kojima obiluju Dubrovnik i Republika Hrvatska, što ostavlja mogućnost novih istraživanja s dosad nepoznatim rezultatima.

Ovaj rad pokazao je upravo to bogatstvo u izradi drvenih brodova na jadranskoj obali samo jednim primjerom trabakula iz 1878., koji svakodnevno, i dok plovi i dok je privezan na kamenu obalu, budi znatiželju za proučavanjem povijesti drvene brodogradnje tijekom stoljeća. Na osnovi priloženih i opisanih materijala može se zaključiti da osim znanja, vještina i umijeća kalafata, koji su se prenosili generacijama, te starih drvenih brodova, uz koje ostaju mnoge zanimljive i nepoznate priče, ostaju i mnogi tradicionalni izrazi i riječi koje se danas ne koriste, a prenošenjem umijeća gradnje brodova i oni su se prenosili generacijama. Sve to ukazuje na bogatstvo koje svakodnevno imamo u neposrednoj blizini, a koje, nažalost, često ostaje nesačuvano i neistraženo da bi se i dalje moglo prenositi budućim generacijama na temelju bogate očuvane kulturne baštinu brodogradnje i kalafatavanja.

\section{LITERATURA / References}

[1] Benčić, R. (2013.): Riječnik govora grada Hvara, Muzej hvarske baštine

[2] Bernardi, T. (1964.): Konstrukcija drvenih brodova, Sveučilište u Zagrebu

[3] Bernardi T. (1975.): DRVENI BROD. Pomorska enciklopedija, sv. 2, str. 245. - 248.

[4] Braica, S. (2015.): Kratki pojmovnik o moru, ribarstvu i pomorstvu, Etnologica Dalmatica, br. 22

[5] Dvornik, J., Dvornik S. (2013.): Konstrukcija broda, Pomorski fakultet u Splitu, str. 9. -10.

[6] European Maritime Heritage, 2005., London

[7] Kalogjera, D. (1998.): The shipbuilding of Korčula, Prometej, Zagreb

[8] Karabaić, V. (1989.): TRABAKUL. Pomorska enciklopedija, sv. 8, str. 186. - 187.

[9] Kisić, A. (2004.): Zakonodavstvo i praksa u zaštiti pomorske baštine Hrvatske, Informatica museologica, Vol. 35, br. 3.- 4.

[10] Kozličić, M. (1993.): Hrvatsko brodovlje. Split-Zagreb

[11] Ilijanić, Z. (2010.): Brodovi od drveta, Prijedlozi očuvanja kulturne baštine

[12] Leibenfrost, A. (1966.): BROD, Konstrukcija drvenog broda. Tehnička enciklopedija, sv. 2, str. 279. - 282

[13] Mardešić, P. (1972.): BROD, Povijesni razvoj trgovačkih brodova. Pomorska enciklopedija, sv. 1, str. 457.- 472.

[14] Marinac, B. (1997.): Ladjedelništvo, Zbornik Primorske - 50 let, Koper

[15] Markovina, R. (2017.): Trabakul, Hrvatska tehnička enciklopedija, Leksikografski zavod Miroslav Krleža

[16] Radić, D. (2015.):Tradigijska trogirska brodogradnja, Etnologica dalmatica, br. 22

[17] Rossi Radić, I. (2015.): Osnovna terminologija za potrebe arheologije broda, Archaeologia Adriatica, 415. - 255.

[18] Salamon,V., Bobanac, N. (2005): Metodologija i kriterij za procjenu autentičnosti tradicijskog broda, HAZU, Zagreb

[19] Salamon, V. (2009.): Jadranska bracera, Broodgradnja 60, str. 99. - 100.

[20] Salamon V. (2016.): Hrvatski tradicijski brodovi. U: More - hrvatsko blago (zbornik radova). Zagreb, str. 673. - 710.

[21] Stolac, D. (1988.): Hrvatsko pomorsko nazivlje,lzdavački centar Rijeka

[22] Stulli, B. (1984.): Dubrovačka Republika, Jugoslovenska enciklopedija, svezak I, Zagreb, str. 607. - 644.

[23] Vidan, P. (2012.): Pomorstvo Šolte, Pomorski fakultet Split, str. 390. - 399.

[24] Urban, Bego, M. (2010.): Škrinje uspomena: Dubrovački jezični pabirci, biblioteka Zavičaj

URL1 https://www.zakon.hr/z/340/Zakon-o-za\%C5\%A1titi-i-o\%C4\%8Duvanju-ku Iturnih-dobara

URL 2 http://www.hrvatski-brodari.com/drveni\%20brodovi\%20i\%20brodograd nja\%20u\%20drvu.pdf

URL3 https://dalmatinskiportal.hr/zivot/dalmatinsko-evandelje--cesmina-i-borovi na/35111

URL4 https://tehnika.Izmk.hr/tradicijska-brodogradnja 